This Section of Epidemiology and Psychiatric Sciences appears in each issue of the Journal and is dedicated to all forms of creative production born of an intimate and individual urge, often secretive, unbound from the conventional art system rules. Through short descriptions of the Outsider art work of prominent artists and new protagonists often hosted in community mental health services, this Section intends to investigate the latest developments of the contemporary art scene, where the distances between the edge and the centre are becoming more and more vague.

Carole Tansella, Section Editor

\title{
Watts Towers. Sam Rodia as a contemporary artist
}

\section{A. Dal Lago and S. Giordano}

Università di Genova, Italy

Received 22 April 2015; Accepted 23 April 2015

Key words: Outsider art, contemporary art, Watts Towers, environments.
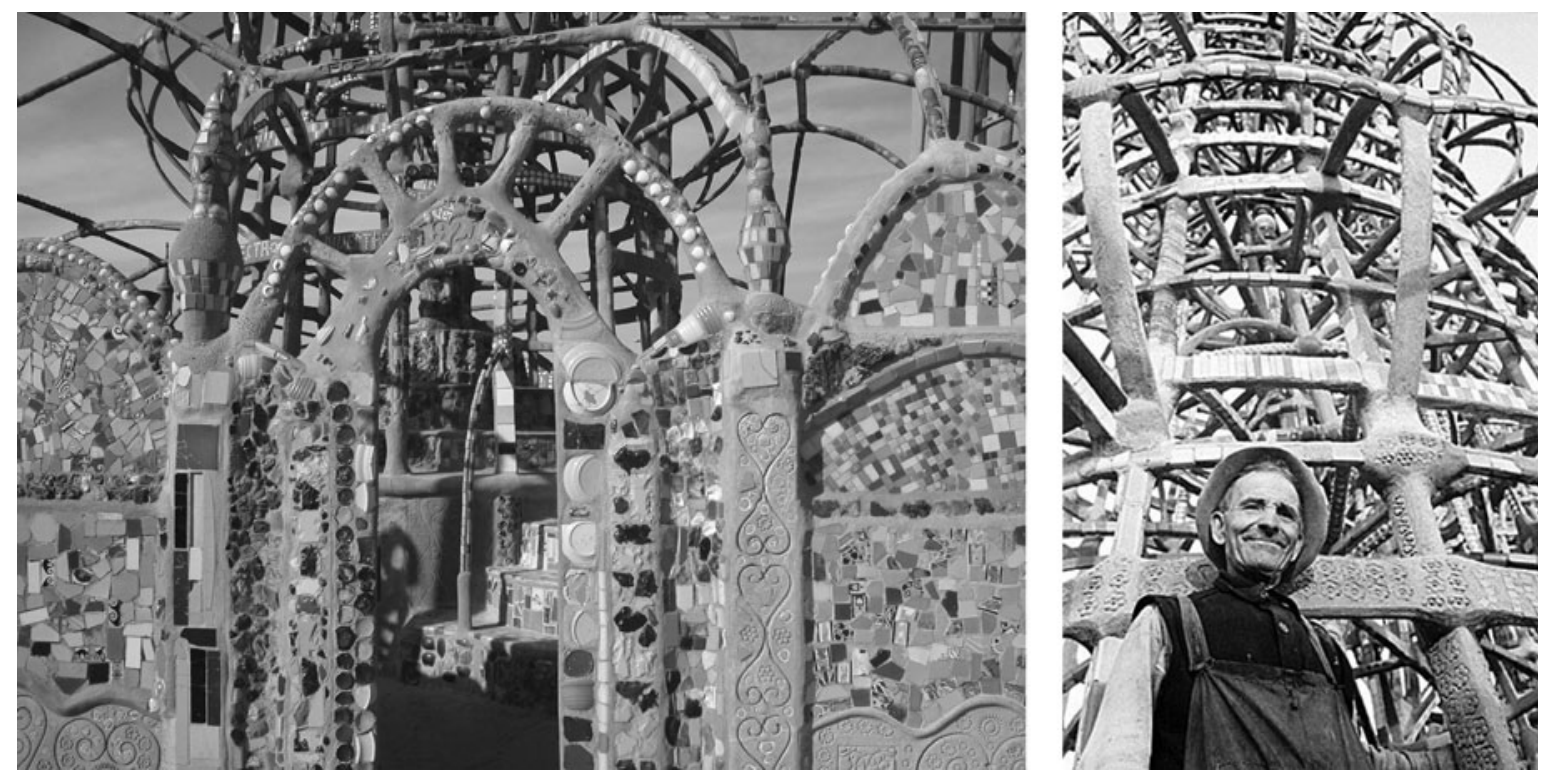

Watts Towers, detail, photo by the authors

Sam Rodia at work, credits Watts Towers and Arts Center, Los Angeles, California

In 1921 'Sam' Rodia bought a small piece of land in Watts, South Central Los Angeles. Rodia was an illiterate immigrant to the USA who made an important art statement on this parcel of property in his adopted home. Over the period of several decades he built seven towers

Address for correspondence: A. Dal Lago, Accademia delle Belle Arti, Palermo, Italy

(Email: dallagoal@gmail.com) made of disparate materials: concrete, pieces of steel, pottery and other objects. Sam Rodia worked on his creation until 1954. Nobody helped him. Why did he do it? How can we define the Watts Towers?

The answers to these questions are perplexing. Over the time, the towers became the main public symbol of Los Angeles (Banham, 1971; Davis, 1992), quitting the realm of outsider art and crossing the border of official art. And yet, the cost of their social inclusion, in becoming a monument on a postcard, has been the exclusion 
of Sam Rodia from the towers. His work was separated from him, and he was left outside the official border. The reason for this exclusion is that he was not considered an artist. Rodia continues to be labelled as an outsider artist. But by changing the frame of reference, he gains many new artistic identities: as pop artist, conceptual artist, performer and land artist.

Jean Dubuffet was the first to create a theory about Art Brut, which he defined as the art of mentally ill persons, prisoners, children and people who live in exotic countries. Of course this is a very strange mix. According to Dubuffet, the common denominator of these categories of artists is that they do not know what they are creating and why. By implication, official artists know what they are doing and why. As we stated in our books on contemporary art, we think this a mere preconception (Dal Lago \& Giordano, 2006, 2008). Consider, for example, Jackson Pollock. He used to say: 'When I'm inside my artwork I never know what I'm doing.' (Naifeh \& White Smith, 1998). For his part, Picasso used to say: 'I don't look for something, I find it'. We think that the case of Rodia, as many other artists who are constrained in the category of 'outsider artists', furnishes much evidence to demonstrate that they work starting from an idea, changing it in progress, while they actualize it. It is the same with Pollock and Picasso, not to mention many others.

The main difference between Picasso and Rodia is that the first lived inside the territory of official art and the second lived outside it. Rodia said many things about himself and about his art, but the art scholars were not interested in it. But the most important message that Rodia transmitted to us was his last statement: 'I don't want anything to do anymore with that. It's done. Excuse me.' If somebody had listened to him, it would be easy to understand the conceptual nature of his work. Rodia tried to explain that the Watts towers were not important for him as artefacts. The main feature of his artwork was to build it: in other words, the act of creation. From this perspective, he was a true conceptual artist. Rodia gave up his artwork as Marcel Duchamp probably discarded his famous 'Fountain'. Both artists were interested in the conceptual process involved in the creation of their artworks.

In using common objects and materials, Rodia changed their status, transforming them into ready-made artworks. Moreover, we can say that Rodia was a pop artist. He had in the twenties the same aesthetic intuition the pop artists had in the sixties: he understood the strong communicative power of common objects. But perhaps the most important feature of his work is the action itself. He had an audience: the people of Watts. They probably understood his performance. They saw him while he was working. It was exactly what Rodia wanted. We know that the meaning of the performance, considered as an artistic language, is to create something in front of an audience. In this case, it is not important what, at the end of the performance, is left. It is only important what somebody actually does, and the audience is essentially incorporated in the performance.

For all these reasons it is not exaggerated to affirm that Sam Rodia's art is ahead of his and our time.

\section{References}

Banham R (1971). Los Angeles: The Architecture of Four Ecologies. Allen Lane: London.

Dal Lago A and Giordano S (2006). Mercanti d'aura. Logiche dell'arte contemporanea. Il Mulino: Bologna.

Dal Lago A and Giordano S (2008). Fuori cornice. L'arte oltre l'arte. Einaudi: Torino.

Davis M (1992). City of Quartz: Excavating the Future in Los Angeles. Vintage: London.

Naifeh S and White Smith G (1998). Jackson Pollock: An American Saga. Woodward/Smith: New York.

\section{About the Author}

Alessandro Dal Lago, Professor and former Dean at the University of Genova, has taught Sociolgy of Culture in Italy at the University of Milan and at the University of Bologna and Visiting Professor at the University of Pennsylvania and at the University of California, Los Angeles.

Dal Lago has extensive experience in Classical Sociological Thought, Contemporary Philosophy of Politics and Society, Migrations and Multiculturalism, Sociology of Arts and Literature and has contributed numerous publications to these areas.

Among his recent publications are:

Mercanti d'aura. Logiche dell'arte contemporanea, Il mulino, 2006; Fuori cornice. L'arte otre l'arte, Einaudi, 2009; L'artista e il potere. Episodi di una relazione equivoca, Il Mulino, 2014; all written with Serena Giordano.

Serena Giordano, Professor at the Academy of Fine Arts of Genova and at the Academy of Fine Arts of Palermo, and Visiting Scholar at the Nordic School of Art of Kokkola, Finland, works also as visual artist and illustrator.

In her research Giordano raises uncomfortable and crucial questions on the dynamics of Contemporary Art, revealing common fallacies and prejudices.

In addition to the books with Alessandro Dal Lago, Serena Giordano is the author of Disimparare l'arte. Manuale di antididattica, Il Mulino, 2012.

Among her major exhibitions are:

Cheap stuff, Palermo, 2014; Saints and the city, Milan, 2010; and I miracoli contemporanei di Santa Rosalial Contemporary Miracles of Santa Rosalia, Palermo/ Helsinki-Kokkola, 2008-2009.

Carole Tansella, Section Editor 